\title{
Conflict and Peace Building: A Study of Women Organizations of Northeast India
}

\author{
Prof. Joyati Bhattacharya
}

\begin{abstract}
The women in Northeast India have traditionally performed an important role in the peace process of the region. Women's increasing participation in the peace process of Northeast is being considered as silver lining in otherwise doomed situation of the region. But what is disappointing is that when women's role in the peace process is praised and encouraged, their foray in active politics is being frowned upon. Despite their remarkable contribution, women in Northeast India could not make an expected assertion in the political process of the region. Women's peace movement in Northeast still has a long way to go to be an independent movement, not dictated by the terms of patriarchy.
\end{abstract}

Keywords- Conflict, Civic Sphere, Peace politics

\section{INTRODUCTION}

Those who are at war with others are not at peace with themselves William Hazlett

Any disturbed region of the world has witnessed a sustained peace building process. Northeast India is not an exception to that. In fact, as an inclusive democratic process, peace building requires involvement and co-operation of all stakeholders. Incidentally, women are always found to be the most important stakeholders in any peace struggle. The vulnerability of women often acts as a catalyst for them to assume a variety of roles in a politically disturbed society. This is probably the reason that leads women to contribute significantly in any trouble-torn society. Research suggests that in many countries women have not only proved to be extremely creative in developing survival mechanisms, but they have also played important role, though unacknowledged in most cases, in ending organized violence of long duration and intense dimension in many turbulent societies. Something of such kind happened in Northeast India also. Thus, Northeast India which is experiencing five decades of political unrest, frequently escalating to insurgency and armed conflict, has created space for the involvement of women in peace building more as a corollary response to the changing scenario of the region than any actual consciousness on the part of women. However, with passage of time, the nature of involvement has assumed a pervasive form with women found to have been engaged in the peace process of any part of Northeast India, irrespective of it being tribal or non-tribal. Ironically, women's status as second-class citizens has given them an advantage to find

Joyati Bhattacharya, Professor, Department of Political Science, Assam University, Silchar, Assam, India innovative ways to deal more proficiently with the problem of peace. Because women are not ensconced with the mainstream, those in power consider them less threatening and thus not worthy of subversion. This has given the opportunity to the movement to grow and act as a vehicle of positive change in otherwise doomed situation of the region. Such increasing participation of women has not only helped stabilizing the fragile society of Northeast from breaking apart completely but also enabled women to come out of their exclusive private domain to assert in the so long unfamiliar public sphere of life. Political Scientist Anuradha Dutta sums up the change in the words that "In Northeast India which has a history of conflict for more than five decades, women have been kept from peacemaking processs....(But) now in place like Nagaland, Manipur and Assam, women activists are playing a positive role and are able to articulate a view of peace and security with social justice, women's rights, economic rights, co-existence, tolerance and participatory democracy as its core". ${ }^{1}$ Rita Manchanda summarized such affirmative response of women to the ongoing demand of the time by saying that "Traditionally here was no space for Naga Women in the indigenous structures of power and representation but Naga Women's peace activism has opened up for the women a recognized space in civil society",

\section{Methodology}

The present study is a descriptive analytical work which was carried out mainly on secondary sources. As women's participation in the peace building process of a conflict ridden society is a common phenomenon in any part of the world, there is plenty of literature dealing with the subject-matter. There is no exception to that in case of Northeast as well. In the process of resolution of long sustained conflict of Northeast, many of the women organizations have made decisive contribution. There is a whole range of literature that highlights various aspects of women's involvement in the peace-building process of Northeast India. For the sake of the present study, a critical analysis of the existing literature is made to derive the conclusions which emphasizes on the aspect of women's marginalization beyond the sphere of civic society. Thus, the primary objective of the study was to understand the role of the women's organization and the causes of their marginalization in the civic sphere of life. 


\section{CONCEPTUAL FRAMEWORK}

When it is not difficult to subsume the contribution of women in a gender neutral narrative of civil society's activism, there is need for a specific focus on the role of women. Such approach is generally driven by the belief that there is perceptible 'difference' in women's style of doing politics and what can women contribute to developing an inclusive and consensual politics. It is generally understood that women's ability to reach across divides is motivated by their inner feminine instincts and therefore more effective to create the space to enable the growth of understanding and consensus. The experiences reveal that women have a capacity to transcend their variegated identities to act as a neutral group to pave the path of social healing. A gender perspective thus enables us to explore what difference women make as opposed to males in peace deals.

\section{ARE WOMEN PEACEFUL}

In mapping women's contribution to peace building, it is seen that women have traditionally been considered as more competent peacemakers as they are more collaborative than men and thus more inclined toward consensus and compromise. Women often use their role as mothers to cut across international borders and international divides. While participating in a peace negotiation, women generally keep the future of their societies and their communities in mind. They think hard to ensure a peaceful future for their children and grandchildren. Like man, immediate power dispensation of the post-conflict era does not constitute an important aspect of women's peace perspective. A glimpse into the peace movements of the world shows that on various occasions, women have shown more patience and far sight in negotiating peace than their male counterparts. During the peace talks that led to the Good Friday Agreement in Northern Ireland, male negotiators often walked out of sessions, leaving a small number of women like Monica McWilliams and other members of the Northern Ireland Women's Coalition at the table. These women focussed on mutual concerns and shared vision, enabling the dialogue to continue and trust to be rekindled. Luz Mendez, the sole woman negotiator in talks to end the decades-long civil war in Guatemala, was able to build consensus among representatives of the warring factions, civil society and the United Nations by creating effective strategies. She was also successful to engage the different parties around to uphold the concerns of women in the peace process. As an acknowledgement of her contribution, the final treaties of the agreement that marked the end of conflict in Guatemala, contained unprecedented commitment to gender equity. It is in context of such examples of women's contribution, Kofi Annan, the former Secretary General of the United Nations, said "For generations, women have served as peace educators both in their families and in their societies. They have proved instrumental in building bridges rather than walls". Reiterating the same view-point, Harris Silajdzic, the former Prime Minister of Bosnia, says "If we'd have women around the table, there would have been no war; women think long and hard before they send their children out to kill other people's children" 4

But not only as negotiators but also as initiators, women have done commendable job in consolidating peace movement as a powerful instrument of change in the society across the globe. In early 2005, the murder of a former colleague, Robert McCartney by his own IRA (Irish Revolutionary Army) colleagues instigated the sisters of McCartney to the settling of scores against that influential terrorist outfit. The five sisters and his fiancé started a sustained and systematic campaign and propaganda against the criminalization of this erstwhile revolutionary organization, i.e., IRA and its gun culture. So vigorous was the campaign by these six women that within six months the IRA was compelled to declare that henceforth they would shun all forms of violence and adopt political negotiations as a tool to achieve their objective. Women played a significant role in reinstating peace in El Salvador. Not only were women believed to have comprised 40 percent of the total combat forces of the revolutionary FMLN (Farabundo Marti National Liberation Front), but even after the war they had been equally instrumental in the political process that have since shaped their nation. El Salvadoran women lobbied actively to include women and ensure gender equality within FMLN and their advocacy led to the establishment of a Women's Secretariat in 1993 and the implementation of 30 percent of quota for the women in FMLN in 1996. As the minister of Gender and Social Affairs in Rwanda, Eloisa Inyumba created programmes to bury the dead, find homes for more than 3000000 orphaned children and resettle refugees after the genocide of 1994. She also served as executive secretary of the National Unity and Reconciliation Commission which organized national debates promoting reconciliation between Hutus and Tutsis and also served as the governor of Kgali-Ngali Province of Rwanda. Nadak Pok is another important woman who has contributed remarkably to promote women's participation in the political process as and when Cambodia was struggling to recover from PolPot's nightmare. Her organization, Women For Prosperity, has trained more than 5000 women to hold political and public offices, enabling 64 percent of the women to be elected to local commune councils of Cambodia in February, 2002. During the violence of the first Intifada in the Middle East, Israeli and Palestinian women like Naomi Chazan and Sumya Farahat Nasser created Jerusalem Link, an umbrella group of women's centres on both sides of the conflict, to convey to the public a joint vision for a just peace. The list may be carried forward to show many more examples of women's involvement at various stages of building up of peace in a society and as well as asserting in the political process of the country as a natural response of their preceding action. In fact, if women begged most number of Nobel Prizes in any particular field, it was in the sphere of peace. So far sixteen women have been awarded Nobel for their endeavour in peace including Malala Yousafzai of Pakistan . 
However, such contribution of women in global peace and security remained unacknowledged long after the creation of the United Nations also. It was after long 55 years that on International Women's Day in the year 2000 that the President of the U.N Security Council issued for the first time a statement that recognized the unacknowledged and the undervalued contribution that women have made or can make to preventing war, to building peace and to bringing individuals and societies back in harmony. It was such recognition of the role of women that led to the adoption of the now famous Security Council Resolution well known by its number 1325. The impact and implication of the Resolution 1325 is enormous. Women and many men all over the world have energized by this resolution, and political support for its implementation by U.N members, international organizations, and most importantly civil society is growing every day. However, the most important contribution of the Resolution is that it establishes an unanimity of opinion about women's contribution to peace building in any politically disturbed society across the globe.

\section{SCENARIO IN NORTHEAST INDIA}

Like women in any other part of the world, women in Northeast India have also come to play a distinctive role over time in the conflict-ridden society of the region. In fact, in Northeast women have always been at the forefront of peace initiatives. The most reputed of women peace workers in Northeast India are generally known to be the Naga Mothers' Association (NMA). The Association was born on February 14, 1984 with a preamble which stated that the Naga Mothers felt the need of 'conscientising citizens' towards a meaningful life and human development. It adopted the principle of "Shed No More Blood" as its motto. Along with development of insurgent threat in Northeast, Naga Mothers' Association emerged as an important civil society organisation of Nagaland and participated actively in the mediation of peace between the Government of India and the NSCN (IM) to facilitate the ceasefire of 1997. Besides, there is another Naga Women's Organization called the Naga Women's Union of Manipur (NWUM) which collaborated actively with the NMA in mobilising people's awareness and reconstructing peace in Naga inhabited areas of the state. Along with the two, the contribution of Kuki Women's Association of Manipur is also worth mentioning. During the Naga-Kuki conflict in the 1990s, women's groups on both sides - the Naga Mother's Association and the Kuki Women's Association-were said to have been engaged with their respective "boys" to stop violence. These women's groups went long stretches, walking for three to four days in the hills, to negotiate and counsel the boys of their respective underground outfits. ${ }^{6}$ In 1970s, Manipur witnessed the formation of Meira Paibi, an women organization of the 'Torch Bearers' in which women would go around their localities with lit torches and detain young males indulging in asocial activities like drinking and so on. By the 1980s, the Meira paibi came to be acknowledged for their influence within the community and during the same time their purpose has also got split. In the absence of an apex body to coordinate the activities of various groups, Meira Paibis sometimes started acting on behalf of the insurgents by alerting the community about imminent army patrols and sometimes negotiating with the army when men of their community were detained. But such irregular incidents do not, however, overshadow the unrelenting drive of the organisation for restoring order in the social life of Manipur. In Assam too, the women have created a niche for themselves in non-formal sectors of peace initiative. Award winning author, Mamoni Raisom Goswami, mediated for peace between the United Liberation Front of Assam (ULFA) and the State of India on her own without associating herself with any formal organization. The other strong women's movement that came about was the establishment of Tangkhul Shanao Long (All Tangkhul Women's Association) and the North East Network (NEN) which was set up in 1994 to represent the cause of the women of Northeast in the World's Women Conference in 1995. Mention may be made of Mizo Women's Federation called Mizoram Hmechche Insuihkhawm Pawl (MHIP) which was founded in 1974 and Khasi Women's Organization like Lympung Ki Synjuk Ki Seng Kynthei. Besides, Bodo Women's Justice Forum, All Bodo Women's Welfare Federation, Kasturba Gandhi Memorial Trust, Matri Mancha, Anchalik Mahila Samitis and Sajagta Samiti of Assam are also important women organizations of Northeast.

\section{THE CRITICAL QUESTION}

Thus, there is no want of evidence to articulate women's presence and involvement in the peace process of Northeast. Not only in reciprocation of the deteriorating situation of Northeast's life, but traditionally as well woman has been considered as messengers of peace in Northeast. The example of the custom of Pukrelia among Nagas may be referred in this context. According to this custom, women arbitrate in conflicts between kinsmen and holding a ' $\mathrm{Y}$ ' stick appeal for the end of rivalry among the men folk. But the critical question that remains unresolved in this apparent show of women's activivism is the conscious exclusion of them from the process of power sharing at the time of reaping the dividends of peace initiative. When women's role in the peace process is welcomed, their foray in active politics is being frowned upon. It is a disheartening reality that in spite of having significant role in saving the fragile society of Northeast from breaking down completely, Women's peace initiatives in the region could not assume a pervasive face and altruistic character as it happened in many other parts of the world. It, in fact, could neither transcend beyond the civic sphere of influence of their respective societies nor could rise above the limitation of ethnic affiliations. The effectiveness of women's organizations in working against violence has often remained limited by their identification with ethnic agenda. The case of Manipur may be cited in this regard where Meira Paibis are fighting the cause of Meiteis and the Naga Women's Union is fighting the cause 
of the Nagas of the hill districts of Manipur. Peace is time and again found to have fallen apart by the dichotomy of ethnic identity and the peace movement is often seen captivated by "saving the sons of the soil" syndrome.

There may be a number of reasons which have been primarily responsible for holding back women's participation beyond the sphere of civic life in Northeast India. One is that women's increasing emergence in the peace process of Northeast was more a concomitant and compelling response to the changing situation in the region than any real eagerness and preparedness on their part to change the society. As a result, women could be systematically excluded from the decision-making process and their participation during the conflict could easily be stereotyped mainly as victims in utter disregard of their roles and experiences as mentors of the devastated society. Since peace and conflict are traditionally the issues of man's domain, women and gender issues get easily excluded at the time of settling the question. It does not become too difficult for the patriarchy to confine women within peace politics and not to step out of it to be a stakeholder in the power structure of the state. In fact, men folk even succeed in manufacturing consent from the women that they would refrain from joining active politics. It is due to this that most of the women's organization including NMA are seen to have declared in their manifesto that they are apolitical and state politics is not their field of work. According to a study, such an exclusion of women from active politics is 'deliberate' and dictated by the male politicians. ${ }^{7}$ When a Shillong based woman journalist asked the members of the powerful NMA and NWUM about their exact role in the meetings with the underground leaders based in Bangkok and their role as members of the core group that decides major strategic action plans, their reply was startling and disappointing. "In reply they gave a wry smile and say we only speak to the leadership after consultation between men is over". ${ }^{8}$ In other words, women are consulted after major decisions have been arrived at more because of giving them a sense of consolation than out of the sense to recognise their capability and contribution in evolving the situation to the present stage. When Isac Muivah and Issac Chisi Swu visited Delhi for the first peace talk in 2003, they were hardly accompanied by any woman representative. During that high level discussion, the only role back at home in Nagaland women were assigned to blow hundreds of colourful balloons and hang them as decorative festoons. ${ }^{9}$ when asked about the cause of that exclusion of women, the male members of the powerful Naga HoHo replied that "It is too early to include women now. We have to tread carefully because the peace process is very fragile and the Hoho itself is a body that has just emerged." ${ }^{10}$ The underlying assumption was that women's inclusion would complicate and delay the peace process as they are not meant for this job. Lalzarliani who headed Mizoram's largest Women NGO lamented that "our male folk try to convey the impression that politics is too complex for women". ${ }^{11}$ The truth of the statement is further proved when the NDA government led by the Bhartiya Janata Party proposed to table the long standing Women's Reservation Bill in the Lok Sabha. In fact, the most powerful opposition against the implementation of the bill came from the Northeastern States. The Chief Minister of Meghalaya E.K. Mawlong made a public statement against the bill and did not even feel the need to consult his lone female colleague Roshan Warjir in this regard. While the same was the response of his counterpart in Nagaland Mr. S.C. Jamir, jamir's successor Neiphiu Rio went a step further to declare "Our beautiful darlings are good for politics but not so good in politics." ${ }^{2}$ The fact of the matter is that the prolonged political battle of this region had its own way in involving women with the situation in different roles depending on their nature of experience and exposure to the conflict. In this process, women have become militant or combatant, shelter provider, victim or peace activist. The adoption of none of this role was being made by choice. Instead, it was necessitated by the compulsion of hard circumstances. In front of the eyes of women, their relations, families and communities were disintegrating. In such a scenario, women had no option but to break out of their exclusivity and endeavour to put the society back on track. ${ }^{13}$ As a result, the stronghold of patriarchy remained equally dominant over women in their new role too. Often women have been made to serve the purpose of shield by their male counterparts. In fact, in Northeast where much of the conflict is linked with the ethnic identity, the pressure of patriarchy on women during the conflict is further strengthened as women are seen to be the custodians of culture and tradition. Women's presence in the conflict is seen as a necessity to serve their male counterpart and hence any broad vision of peace is discouraged. Women leaders who have taken initiatives at conflict resolution in a broader spectrum are generally not supported by the community and are looked upon with suspicion. They fall vulnerable to attacks both from certain factions of non-state actors as well as state actors. Women's vulnerability increases depending on the kind of role they want to play in the peace process. Women are accepted as 'healers' or 'pacifiers' but not as one important when they attempt to play a more decisive role and endeavour to link the question of peace with the basic concept of democracy. It is seen that women who protest against state oppression are branded as the 'over ground agents' of the underground terrorist outfits and women who raise voices against the oppression of underground non-state actors are termed as the agents of the State. ${ }^{14}$ Thus, the underlying attempt to control and perpetrate women's subordination continues regardless of whichever category a woman is placed and whatever role a woman is playing in the conflict. It is then obvious that such perpetuation of patriarchy will have its effect in shrinking women's domain to the civic sphere of life in Northeast. 


\section{CONCLUSIONS}

A lasting peace cannot be achieved without adopting a comprehensive approach which includes different stakeholders of the society. Thus, the involvement of women who happen to be major actors and the inclusion of gender perspectives in the peace process is imperative. Any hope of enduring peace, stability and development depend on putting women's rights on the table and assigning them their legitimate space. Unfortunately unlike many other places, the same did not happen in Northeast India. Much of the contribution of women in Northeast has so far constituted an important aspect of gender study rather than forming an actual force of change in the society. But the fact is that in Northeast, women have not only fought against the hostile forces of patriarchy but also struggled hard to diffuse the deep-rooted ethnic and intercommunity divides to forge a common coalition of women at least to a great extent. Unfortunately such efforts could not avert women's marginalization to their pre-conflict status quo in the post-conflict phase. The reason for this is deep-rooted and is embedded not only in the traditional socio-economic structure which deters women's role in other societies too but also in complex demographic make-up of Northeast's life. Whatever is the reason for the same, now it is time for the women of Northeast to redefine their own situation by the politics of peace. Otherwise, the movement will end up only in sounds and fury signifying nothing as such for women.

\section{REFERENCES}

[1] Anuradha Dutta (2004), "Women as Peacemakers: A Study of North east India" in Monirul Hussain (ed), Coming Out of Violence: Essays on Ethnicity, Conflict Resolution and Peace Process in North East india, Regency Publications, New Delhi, pp. 64-75

[2] Rita Manchanda (January 1-14, 2000), "The Peace Makers" in North East Sun, p.24

[3] Quoted in Las Hijas de Erin, "The Role of Women in Northern Ireland Peace Process", www.huntalternatives.org

[4] Ibid

[5] They were Bertha Von Suttner (Austria) in 1905; Jane Adams (U.S.A) in 1931; Emily Green Balch (U.S.A) in 1946; Betty Williams (U.S.A) in 1976; Mairead Corrigan (Ireland) in 1976 (Betty Williams was a coreceipient with Mairead Corrigan); Mother Teresa (India) in 1979; Alva Myrdal (Sweden) in 1982; Aung San Ki (Myanmar) in 1991; Rigoberta Menchu (Guatemala) in1992; Jody Williams (U.S.A) in 1997; Shirin Ebadi (Iran) in 2003; Wangari Muta Mathai (Kenya) in 2004, Ellen Johson Sirleaf (Liberia) in 2011, Leymah Gbowee (Liberia) in 2011, Tawakel Karman (Yemen) in 2011, Malala Yousafzai (Pakistan) in 2014.

[6] Vijaylakshmi Brara, Women's Role in Human Rights and Peace in Northeast, PUCL Bulletin, February, 2002

[7] Aparna Mohanto (1998) "Working of Parliamentary Politics and Empowerment of Women in Northeast India" in Girin Phukon and AdilUl-Yasin (eds), Working of Parliamentary Democracy and Parliamentary Politics in Northeast India, South Asia Publishers, New Delhi, p. 180

[8] Patricia Mukhim 13 May, 2003,' Nagaland: The Unheard Voice' in The Telegraph, Northeast Page, , p.16

[9] Ibid

[10] Op Cit

[11] "Number Battle Won, but not the Gender War", News Report in The Telegraph, North East Page, 19 November, 2003

[12] Quoted in Patricia Mukhim, "Breaking Gender Barriers", Editorial article in The Telegraph, Northeast Page, 6 April, 2004.
[13] Sajal Nag (2006), "Her Masters' Voice: Women, Peace-making and Genderisation of Politics" in Prasenjit Biswas \& C. Joshua (eds.) Peace in India's Northeast, Meaning, Metaphor and Method, New Delhi, p. 221

[14] Roshmi Goswami (August 2000), "Reinforcing Subordination: An Analysis of Women in Armed Conflict Situation", Research paper presented in WISCOMP Summer Seminar on Human Security in the New Millennium. 